\title{
Reactive perforating collagenosis in two siblings
}

\author{
Manish Bansal, Kajal Manchanda, Anand Kumar
}

Department of Dermatology and Venereology, Institute of Medical Sciences, Banaras Hindu University, Varanasi, Uttar Pradesh, India

\section{Correspondence to}

Dr Kajal Manchanda, kajalmanchanda@gmail.com

\section{DESCRIPTION}

A 5-year-old male child presented with multiple, asymptomatic, raised lesions over dorsum of bilateral hands, feet and face since the age of 1 year. The lesions used to aggravate in winters and heal with superficial scarring. His elder sister (7-years-old) also had a history of similar lesions since the age of 3 years. There was no history suggestive of systemic involvement. Their parents were concerned regarding the superficial scarring on the face. On examination, multiple, discrete, papular lesions with central adherent keratin plug, varying in size from 2 to $5 \mathrm{~mm}$, were present over face, bilateral forearms and legs predominantly distributed over the elbow and knee in both siblings (figure 1A-D). Multiple atrophic scars were also visible over face. Few of the lesions were arranged in a linear distribution. Histopathological examination from a papule over forearm showed a shallow invagination of the papillary dermis containing a mixture of basophilic material and degenerated collagen bundles. Adjacent epidermis showed moderate acanthosis. Haematological investigations including complete blood counts, liver and renal profile and serum blood glucose levels were within normal limits. The diagnosis of reactive perforating collagenosis (RPC) was thus established on the basis of clinical features aided by the histopathological findings.

RPC is a distinct transepithelial elimination (TEE) disorder characterised by umblicated skin coloured papules with central crust. RPC is considered to be a genetic disorder with no associations and presents at an early stage. Superficial trauma causes alteration of collagen in papillary dermis leading to its degeneration followed by perforation of epidermis with transepidermal elimination of necrobiotic material. ${ }^{1}$ The four classical TEE disorders include RPC, elastosis perforans serpiginosa, perforating folliculitis and Kyrle's diseases. There has been an increasing number of reports of
To cite: Bansal $\mathrm{M}$ Manchanda K, Kumar A. BMJ Case Rep Published online: [please include Day Month Year] doi:10.1136/ bcr-2013-009023
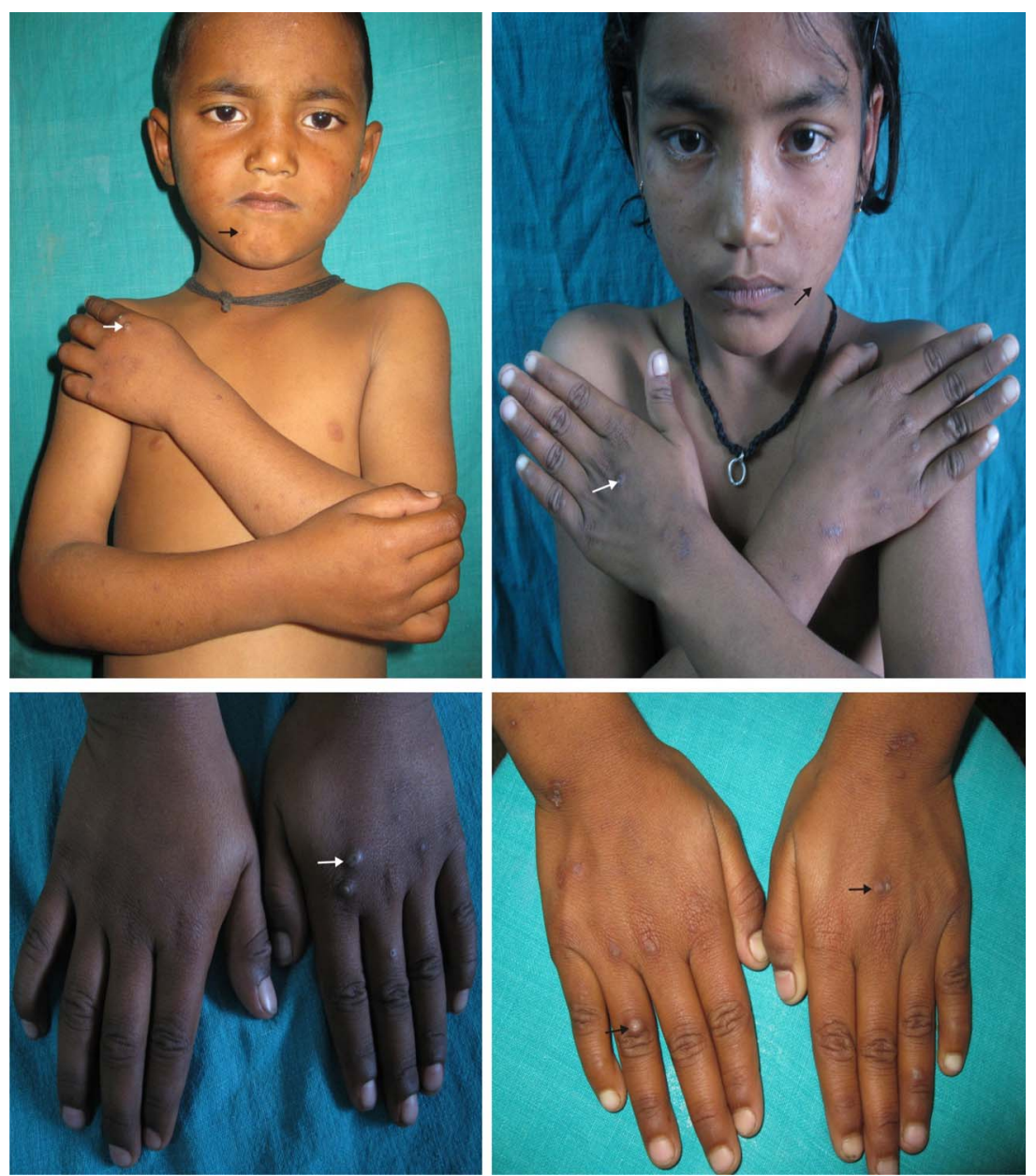

Figure 1 (A, B) Multiple keratotic papules over chin and dorsum of left hand of the male child (arrows). Superficial scarring is present over the bilateral cheeks. (C, D) Similar keratotic papules present over dorsum of right hand in elder sister (arrow). Superficial scarring is present over forehead. 
perforating dermatoses in association with systemic diseases like diabetes mellitus, chronic renal failure, malignancies and liver disorders and hence labelled as acquired perforating collagenosis. Diagnosis is established by the classical morphology of papular lesions with central umblication aided by characteristic histopathology. $^{2}$ Topical retinoids, corticosteroids, oral isotretinoin, methotrexate and Psoralens and Ultraviolet A phototherapy (PUVA) therapy have been shown to be useful in the treatment. ${ }^{23}$

\section{Learning points}

- Reactive perforating collagenosis is a genetically determined rare cutaneous perforating disorder characterised by elimination of altered collagen through the epidermis.

- The disease usually starts in childhood and is characterised by umblicated skin coloured papules with a keratinous plug which leaves a residual scar on healing.

- Diagnosis is established by the clinical presentation and characteristic histopathology.

- Topical retinoids, corticosteroids, oral retinoids, methotrexate and PUVA therapy are useful in the treatment.
Contributors The manuscript submitted is original and valid. This manuscript or one with similar content has not been published or is being considered for publication in any other journal under our authorship.

Competing interests None.

Patient consent Obtained.

Provenance and peer review Not commissioned; externally peer reviewed.

\section{REFERENCES}

1 Prendiville SJ. Acquired perforating disorders. In: Fitzpatrick TB, Wolff K, Goldsmith AL, Gilchrest AB, Paller SA, Leffell JD.eds Dermtology in general medicine. 7th edn. New York, NY: Mc-Graw-Hill, 2008:564-7.

2 Vashishtha R, Agarwal US, Mathur NK. Acquired reactive perforating dermatosis. Indian J Dermatol Venereol Leprol 1993:59:251-3.

3 Serrano G, Aliaga A, Lorente M. Reactive perforating collagenosis responsive to PUVA. Int J Dermatol 1988;27:118-19.

Copyright 2013 BMJ Publishing Group. All rights reserved. For permission to reuse any of this content visit http://group.bmj.com/group/rights-licensing/permissions.

BMJ Case Report Fellows may re-use this article for personal use and teaching without any further permission.

Become a Fellow of BMJ Case Reports today and you can:

- Submit as many cases as you like

- Enjoy fast sympathetic peer review and rapid publication of accepted articles

- Access all the published articles

- Re-use any of the published material for personal use and teaching without further permission

For information on Institutional Fellowships contact consortiasales@bmjgroup.com

Visit casereports.bmj.com for more articles like this and to become a Fellow 